\title{
Adequate timing and constant supervision are the keys for successful implementation of levothyroxine or levothyroxine/ paracetamol absorption test
}

Krzysztof C. Lewandowski „2, Katarzyna Dąbrowska², Magdalena Basińska-Lewandowska², Marek Bolanowski ${ }^{3}$, Marek Ruchała ${ }^{4}$ and Andrzej Lewiński ${ }^{1,2^{*}}$ (i)

\begin{abstract}
Background: Levothyroxine $\left(\mathrm{LT}_{4}\right)$ pseudomalabsorption due to medication non-adherence results in significant costs for Health Service. High dose $\mathrm{LT}_{4}$ or $\mathrm{LT}_{4} /$ paracetamol absorption test is used in such cases. Hence, establishment of an optimal test protocol and timing of sample collection is of utmost importance.

Case presentation: A 34-year old woman was admitted to our Department because of severe hypothyroidism [on admission thyrotropin $(\mathrm{TSH})>100 \mu \mathrm{lU} / \mathrm{ml}$, free thyroxine $\left(\mathrm{FT}_{4}\right) 0.13 \mathrm{ng} / \mathrm{dl}$ (ref. range 0.93-1.7)] despite apparently taking $1000 \mu \mathrm{g}$ of $\mathrm{LT}_{4}$ a day. Autoimmune hypothyroidism had been diagnosed 4 years before during post-partum thyroiditis. Subsequently, it was not possible to control her hypothyroidism despite several admissions to two University Hospitals and despite vehement denial of compliance problems. There was no evidence of coeliac disease or other malabsorption problems, though gluten-free and lactose-free diet was empirically instigated without success. A combined paracetamol $(1000 \mathrm{mg}) / \mathrm{LT} \mathrm{T}_{4}(1000 \mu \mathrm{g})$ absorption test was performed in one of these Hospitals. This showed good paracetamol absorption (from $<2 \mu \mathrm{g} / \mathrm{ml}$ to $14.11 \mu \mathrm{g} / \mathrm{ml}$ at $120 \mathrm{~min}$ ), with inadequate $\mathrm{LT}_{4}$ absorption ( $\mathrm{FT}_{4}$ increase from $5.95 \mathrm{pmol} / \mathrm{l}$ to $9.92 \mathrm{pmol} / \mathrm{l}$ at 0 and $120 \mathrm{~min}$ respectively). About 2 years prior to admission to our Department the patient was treated with escalating doses of levothyroxine [up to $3000 \mu \mathrm{g}$ of $\mathrm{T}_{4}$ and $40 \mu \mathrm{g}$ of triiodothyronine $\left(\mathrm{T}_{3}\right)$ daily] without significant impact on TSH (still $>75 \mu \mathrm{lU} / \mathrm{ml}$, and $\mathrm{FT}_{4}$ still below reference range).

After admission to our Department we performed a $2500 \mu \mathrm{g} \mathrm{LT} 4$ absorption test with controlled ingestion of crushed tablets, strict patient monitoring and sampling at 30 min intervals. We observed a quick and striking increase in $\mathrm{FT}_{4}$ from 0.13 to $0.46,1.78,3.05$ and $3.81 \mathrm{ng} / \mathrm{dl}$, at 0, 30, 60, 90 and $120 \mathrm{~min}$, respectively. Her TSH concentration decreased to $13.77 \mu \mathrm{lU} / \mathrm{ml}$ within 4 days. When informed, that we had managed to "overcome" her absorption problems, she discharged herself against medical advice and declined psychiatric consultation.

\footnotetext{
* Correspondence: andrzej.lewinski@umed.lodz.pl

'Department of Endocrinology and Metabolic Diseases, Medical University of Lodz, Rzgowska 281/289, 93-338 Lodz, Poland

${ }^{2}$ Department of Endocrinology and Metabolic Diseases, Polish Mother's

Memorial Hospital - Research Institute, Lodz, Poland

Full list of author information is available at the end of the article
}

(c) The Author(s). 2020 Open Access This article is licensed under a Creative Commons Attribution 4.0 International License, which permits use, sharing, adaptation, distribution and reproduction in any medium or format, as long as you give appropriate credit to the original author(s) and the source, provide a link to the Creative Commons licence, and indicate if changes were made. The images or other third party material in this article are included in the article's Creative Commons licence, unless indicated otherwise in a credit line to the material. If material is not included in the article's Creative Commons licence and your intended use is not permitted by statutory regulation or exceeds the permitted use, you will need to obtain permission directly from the copyright holder. To view a copy of this licence, visit http://creativecommons.org/licenses/by/4.0/. The Creative Commons Public Domain Dedication waiver (http://creativecommons.org/publicdomain/zero/1.0/) applies to the data made available in this article, unless otherwise stated in a credit line to the data. 
(Continued from previous page)

Conclusions: Adequate patient supervision and frequent sampling (e.g. every 30 min for 210 min) is the key for successful implementation of $\mathrm{LT}_{4}$ absorption test. Paracetamol coadministration appears superfluous in such cases.

Keywords: Levothyroxine, Paracetamol, Acetaminophen, Absorption test, Pseudomalabsorption, Non-adherence, Non-compliance

\section{Background}

Levothyroxine $\left(\mathrm{LT}_{4}\right)$ pseudomalabsorption due to poor adherence, or non-adherence (also termed noncompliance) to prescribed regimen constitutes a rare but serious problem, given the fact that genuine cause of the problem is often denied by patient. Furthermore, such cases are also characterised by poor attendance for follow-up appointments, by some patients, once pooradherence to medication is mentioned [1]. In cases of $\mathrm{LT}_{4}$ non-adherence, a high dose $\mathrm{LT}_{4}$ absorption test is often used [1-3]. Levothyroxine absorption test is also used in cases of suspected interference in TSH and/or free thyroid hormone measurements $[4,5]$.

Levothyroxine absorption test is, however, not standardised, both in terms of optimal timing of sampling, as well as in terms of potential utility of co-administration of paracetamol (acetaminophen), as suggested by some authors [6]. Hereby we present a case of 34-year old female patient with $\mathrm{LT}_{4}$ pseudomalabsorption due to nonadherence to prescribed therapy with a history of multiple admissions to two academic units and two previous $\mathrm{LT}_{4}$ absorption tests that had lead to misleading results leading to a recommendation of treatment with massive doses of $\mathrm{LT}_{4}(3000 \mu \mathrm{g} /$ day $)$.

\section{Case presentation}

A 34 year old woman (height $164 \mathrm{~cm}$, weight $57 \mathrm{~kg}$, BMI $21.2 \mathrm{~kg} / \mathrm{m}^{2}$ ) was referred for investigations in our Department following a dramatic plea from her General Practitioner (GP) addressed to Chief Endocrine Consultant for Poland (AL). Her GP explained that despite treatment with high doses of $\mathrm{LT}_{4}$ and multiple admissions to two University Departments of Endocrinology, as well as to local District General Hospital, her TSH concentrations oscillated between 300 and $500 \mu \mathrm{IU} / \mathrm{ml}$ (ref. 0.27-4.2) with very low free thyroxine $\left(\mathrm{FT}_{4}\right)$ concentrations. In GP opinion, advice received so far had not provided her with "any successful treatment plan". GP also inquired whether administration of intravenous preparations of $\mathrm{LT}_{4}$ would be appropriate in her case. Copies of her previous extensive medical records were enclosed. Hospital admission was organised and the patient was admitted under the care of medical team with particular experience in cases of $\mathrm{LT}_{4}$ malabsorption, as well as assay interference (KCL, KD).
Patient history and review of available documentation revealed that she had been well till about 4 years before (then aged 30), where she developed autoimmune hypothyroidism as post-partum thyroiditis. She denied any history of post-partum depression, while early clinic documentations around the time of diagnosis was unavailable. Approximately 1 year later she developed problems with uncontrolled hypothyroidism despite increasing doses of $\mathrm{LT}_{4}$. Approximately 2 years after diagnosis she was admitted to Department of Endocrinology of another University Hospital. Her weight was $54 \mathrm{~kg}$ and there was no obvious evidence of malabsorption or other hormonal problems. Her TSH, however, was above $75 \mu \mathrm{IU} / \mathrm{ml}$, and she remained profoundly hypothyroid, so a combined $\mathrm{LT}_{4}(1000 \mu \mathrm{g}) /$ paracetamol $(1000 \mathrm{mg}$ type of preparation not specified) absorption test was performed. This showed rather weak absorption of $\mathrm{LT}_{4}$ (about 66\% increase in $\mathrm{FT}_{4}$ concentration), but quite good absorption of paracetamol (where the therapeutic target level of paracetamol was assumed to be 10-20 $\mathrm{mg} / \mathrm{l}$, i.e. $10-20 \mu \mathrm{g} / \mathrm{ml}$ ) [7] (see Fig. 1), at some point she also had $500 \mu \mathrm{g}$ LT4 absorption test (first sample after $120 \mathrm{~min}$ ) that showed only $20 \%$ increase in $\mathrm{FT}_{4}$.

Based on the result of this test the managing team concluded that some genuine malabsorption problems must be present.

As there was also a borderline concentration of antigliadin antibodies (titres of other coeliac disease-related antibodies were normal), she was referred for further investigations in the Department of Gastroenterology, where no obvious abnormalities, apart from tendency to constipation, were found. It should be noted, however, that she declined gastroscopy, as she insisted on the test being performed under general anaesthesia that according to her managing team "was not possible in view of her profound hypothyroidism". Despite the lack of any clear evidence of coeliac disease, an empirical trial of both gluten-free and lactose-free diet was instigated.

This was followed by an attempt to "overcome" her presumed malabsorption with massive doses of $\mathrm{LT}_{4}$, as well as combined $\mathrm{LT}_{4} / \mathrm{T}_{3}$ medication $\left(\right.$ Novothyral ${ }^{\circ}$ ) administered as an inpatient over a 24 day period. Following trial of various combinations of medications (Table 1), with doses of $\mathrm{LT}_{4}$ reaching an enormous $3000 \mu \mathrm{g} /$ day she achieved an increase of free $\mathrm{T}_{3}\left(\mathrm{FT}_{3}\right)$ 


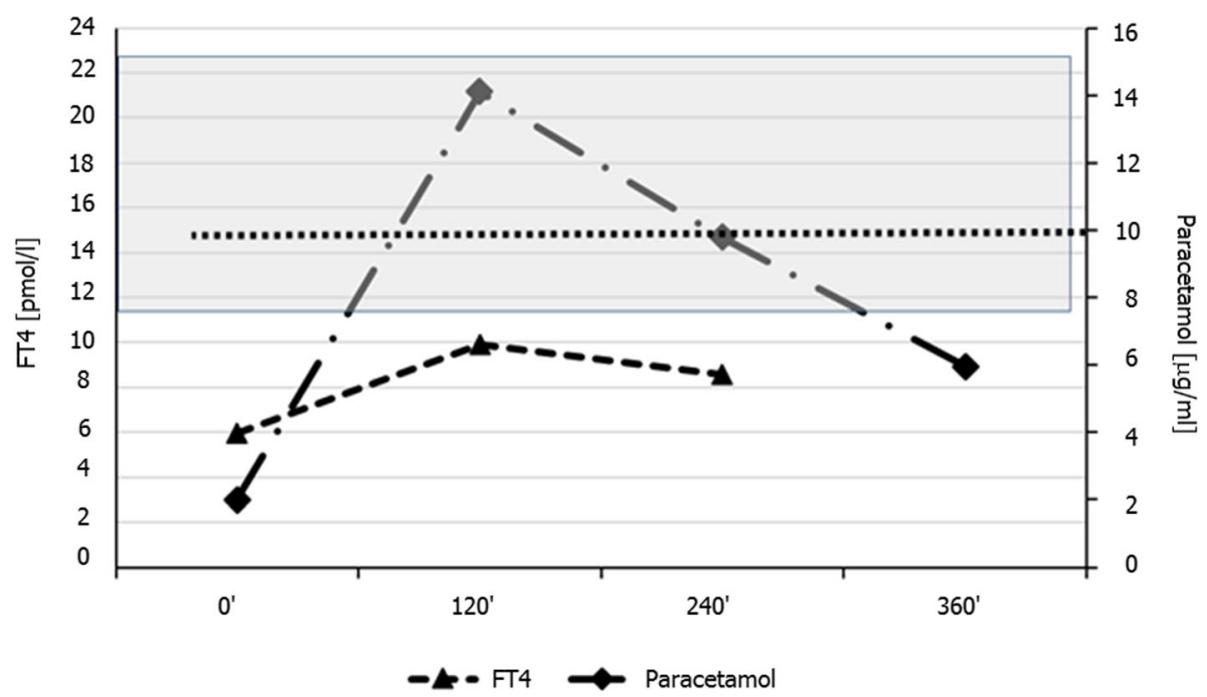

reference range for FT4 $\quad$........ low level of therapeutic range for paracetamol

Fig. 1 Results of combined levothyroxine $(1000 \mu \mathrm{g})$ and paracetamol $(1000 \mathrm{mg})$ oral absorption test in a female patient with suspected levothyroxine malabsorption about 2 years prior to admission to our Department. Darker area represents reference range for free $\mathrm{T}_{4}(11.5-22.7 \mathrm{pmol} / \mathrm{l})$

Table 1 Thyroid hormone concentrations following administration of various combinations of massive doses of levothyroxine and triiodothyronine in order to "overcome" presumed malabsorption of levothyroxine

\begin{tabular}{|c|c|c|c|c|c|}
\hline \multicolumn{6}{|c|}{ Thyroid function tests $(07.2017)$} \\
\hline Date & Time & 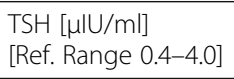 & $\begin{array}{l}\mathrm{FT}_{4} \text { [pmol//] } \\
\text { [Ref. Range 11.5-22.7] }\end{array}$ & $\begin{array}{l}\mathrm{FT}_{\mathbf{3}} \text { [pmol//] } \\
\text { [Ref. Range 2.76-6.45] }\end{array}$ & $\begin{array}{l}\text { Daily dose } \\
\text { p.o. }\end{array}$ \\
\hline \multirow[t]{3}{*}{ Day 1} & $10: 00$ & $>75$ & 4.12 & 3.06 & $\mathrm{LT}_{4} 1700 \mu \mathrm{g}$ and $\mathrm{T}_{3} 40 \mu \mathrm{g}$ \\
\hline & 18:00 & $n m^{*}$ & 3.99 & 3.16 & \\
\hline & $2: 00$ & $\mathrm{~nm}$ & 4.83 & 2.95 & \\
\hline \multirow[t]{3}{*}{ Day 2} & 10:00 & $\mathrm{nm}$ & 4.67 & 3.27 & $\mathrm{LT}_{4} 1700 \mu \mathrm{g}$ and $\mathrm{T}_{3} 40 \mu \mathrm{g}$ \\
\hline & 18:00 & $\mathrm{nm}$ & 4.35 & 3.24 & \\
\hline & $2: 00$ & $\mathrm{~nm}$ & 4.59 & 3.01 & \\
\hline \multirow[t]{2}{*}{ Day 3} & 18:00 & $\mathrm{nm}$ & 4.92 & 2.93 & $\mathrm{LT}_{4} 2200 \mu \mathrm{g}$ and $\mathrm{T}_{3} 40 \mu \mathrm{g}$ \\
\hline & $2: 00$ & $\mathrm{~nm}$ & 4.38 & 2.87 & \\
\hline \multirow[t]{3}{*}{ Day 4} & $8: 00$ & $\mathrm{~nm}$ & 6.38 & 2.86 & $\mathrm{LT}_{4} 3200 \mu \mathrm{g}$ and $\mathrm{T}_{3} 40 \mu \mathrm{g}$ \\
\hline & 18:00 & $\mathrm{nm}$ & 5.73 & 3.29 & \\
\hline & $2: 00$ & $\mathrm{~nm}$ & 5.78 & 3.55 & \\
\hline Day 5 & $8: 00$ & $\mathrm{~nm}$ & 5.96 & 2.93 & $\mathrm{LT}_{4} 3200 \mu \mathrm{g}$ and $\mathrm{T}_{3} 40 \mu \mathrm{g}$ \\
\hline Day 6 & $8: 00$ & $\mathrm{~nm}$ & 6.64 & 3.9 & $\mathrm{LT}_{4} 3200 \mu \mathrm{g}$ and $\mathrm{T}_{3} 40 \mu \mathrm{g}$ \\
\hline Day 7 & $8: 00$ & $\mathrm{~nm}$ & 6.96 & 3.62 & $\mathrm{LT}_{4} 3200 \mu \mathrm{g}$ and $\mathrm{T}_{3} 40 \mu \mathrm{g}$ \\
\hline Day 15 & $8: 00$ & $\mathrm{~nm}$ & 6.62 & 3.81 & $\mathrm{LT}_{4} 1700 \mu \mathrm{g}$ and $\mathrm{T}_{3} 40 \mu \mathrm{g}$ \\
\hline Day 24 & $8: 00$ & $>75$ & 5.53 & 4.19 & $\mathrm{LT}_{4} 3000 \mu \mathrm{g}$ \\
\hline
\end{tabular}


from 3.06 to $4.19 \mathrm{pmol} / \mathrm{l}$ (ref. Range 2.76-6.45), however, without any measurable impact on TSH concentrations and only a $20 \%$ increase in $\mathrm{FT}_{4}$.

On admission to our Department the patient was biochemically profoundly hypothyroid [TSH $>100 \mu \mathrm{IU} / \mathrm{ml}$, $\mathrm{FT}_{4} 0.13 \mathrm{ng} / \mathrm{dl}$ (ref. range 0.93-1.7)] despite apparently taking $1000 \mu \mathrm{g}$ of $\mathrm{LT}_{4}$ a day. Her skin was dry and ankle reflexes were markedly delayed. She seemed, however, to be very well adopted to her hypothyroid state, blood pressure was $116 / 74 \mathrm{mmHg}$, heart rate 70 beats/minute, with a history of only $3 \mathrm{~kg}$ weight gain over 2 year period. Her periods were heavy and mildly irregular (every 34-45 days). Interestingly, no third party was authorised by the patient to be informed about her medical condition, even though she admitted that she was living with a partner. As an initial part of investigation we performed serial TSH dilution test, in order to rule out possible assay interference (Table 2). This is the standard procedure to demonstrate linearity of hormone concentrations following serial dilutions [8].

Taking into account that she had been apparently taking $1000 \mu \mathrm{g}$ of $\mathrm{LT}_{4}$ a day, a $2500 \mu \mathrm{g}$ (i.e. 2.5 times her presumed daily dose) $\mathrm{LT}_{4}$ absorption tests was performed. She received crushed tablets of standard $\mathrm{LT}_{4}$ preparation (Euthyrox $\mathrm{N}^{\circ}$ ), with a lactose-containing base. The test was, however, performed under strict supervision. In particular, the patient was told to remain for an entire duration of the test in the room, where endocrine dynamic tests are performed in our Department. Blood samples were taken every $30 \mathrm{~min}$. Several nurses and other patients undergoing dynamic tests of pituitary function (such as glucagon stimulation test) were also present in the same room.

Under these circumstances, $\mathrm{LT}_{4}$ absorption test revealed an excellent absorption of $\mathrm{LT}_{4}$, with $\mathrm{FT}_{4}$ concentrations surpassing upper limit of $\mathrm{FT}_{4}$ reference range at $60 \mathrm{~min}$ and reaching concentrations about 25 times above the baseline $\mathrm{FT}_{4}$ concentration at $120 \mathrm{~min}$ of the test (Fig. 2). This was followed by a marked decrease and near normalisation of TSH concentration after 4 days.

As we were not convinced that general anaesthesia was indeed necessary for gastroscopy in the setting of hypothyroidism, and in view of clinical anaemia (haemoglobin $8.1 \mathrm{~g} / \mathrm{dl}$ ) with iron deficiency, standard

Table 2 Results of TSH dilution test performed on a day prior to LT4 absorption test

\begin{tabular}{lll}
\hline TSH sample dilution & TSH $[\mu \mathrm{IU} / \mathrm{ml}]$ & TSH $[\mu \mathrm{U} \mathrm{U} / \mathrm{ml}]$ after recalculation \\
\hline No dilution & 289.3 & 289.3 \\
1:4 & 72.8 & 291.2 \\
$1: 16$ & 19.7 & 315.2 \\
1.32 & 10.1 & 323.2 \\
\hline
\end{tabular}

gastroscopy with duodenal biopsies was performed. This showed evidence of Helicobacter pylori infection, but failed to demonstrate any histological evidence of villous atrophy (grade "nil" on Marsh scale of duodenal atrophy) [9].

The patient was subsequently informed that we had managed to overcome her "absorption problems". In such circumstances she discharged herself against medical advice. She declined any psychological or psychiatric consultation. We suggested $\mathrm{LT}_{4}$ (Euthyrox No) $200 \mu \mathrm{g} /$ day (still a high dose of about $3.5 \mu \mathrm{g} / \mathrm{kg}$ of body weight), as well as Helicobacter pylori eradication course, with an outpatient check-up of thyroid function after 4-5 weeks. We also suggested a possibility of supervised weekly ingestion of $1400 \mu \mathrm{g}$ of $\mathrm{LT}_{4}$ once a week, with possible further decrease of the dose to about $1.6 \mu \mathrm{g} / \mathrm{kg} /$ day ( $90-100 \mu \mathrm{g} /$ day) in the outpatient setting, depending on her TSH and fT4 concentrations.

\section{Discussion}

Our study demonstrates a case of severe and prolonged $\mathrm{LT}_{4}$ pseudomalabsorption due to do non-compliance linked with manipulative behaviour. This psychiatric disorder, known as factitious disorder, is characterised by lying, sometimes involving the use of aliases, multiple hospital admissions without specific reasons, and extensive knowledge of medical symptomatology $[10,11]$. The purpose of such behaviour is to adopt the "sick role" that may be associated with some form of gratification, e.g. release from daily duties, centred attention of family members, etc. A psycho-analytic explanation formulated by O'Shea [12] suggests that feeling of neglect and being abandoned are the underlying reasons for such behaviour.

In such cases, if associated with non-adherence to $\mathrm{LT}_{4}$ treatment, a $\mathrm{LT}_{4}$ absorption test may be used [1, 2, 11, 13]. It is documented that peak concentrations of $\mathrm{FT}_{4}$ are typically observed about $120 \mathrm{~min}$ after test dose [2, $11,13,14]$, though data of Ching Sun et al. [3] suggest that almost peak concentrations of $\mathrm{FT}_{4}$ may be observed as soon as between 60 and $90 \mathrm{~min}$ after the test dose. It is not entirely clear what extent of FT4 increase should be considered an adequate response during LT4 absorption test. Soares et al. [15] suggest that an increase in FT4 concentration should be at least 2.5 times above the baseline concentration as long as the initial FT4 concentration is below the lower limit of reference. Absorption of LT4 can be further enhanced if the tablets are administered in a crushed form [16].

In our case, we have documented, however, an excellent absorption of $\mathrm{LT}_{4}$ despite evidence of rather poor absorption during previous $\mathrm{LT}_{4}$ absorption tests performed in other institutions. In one of these tests quite good absorption of paracetamol was observed despite 


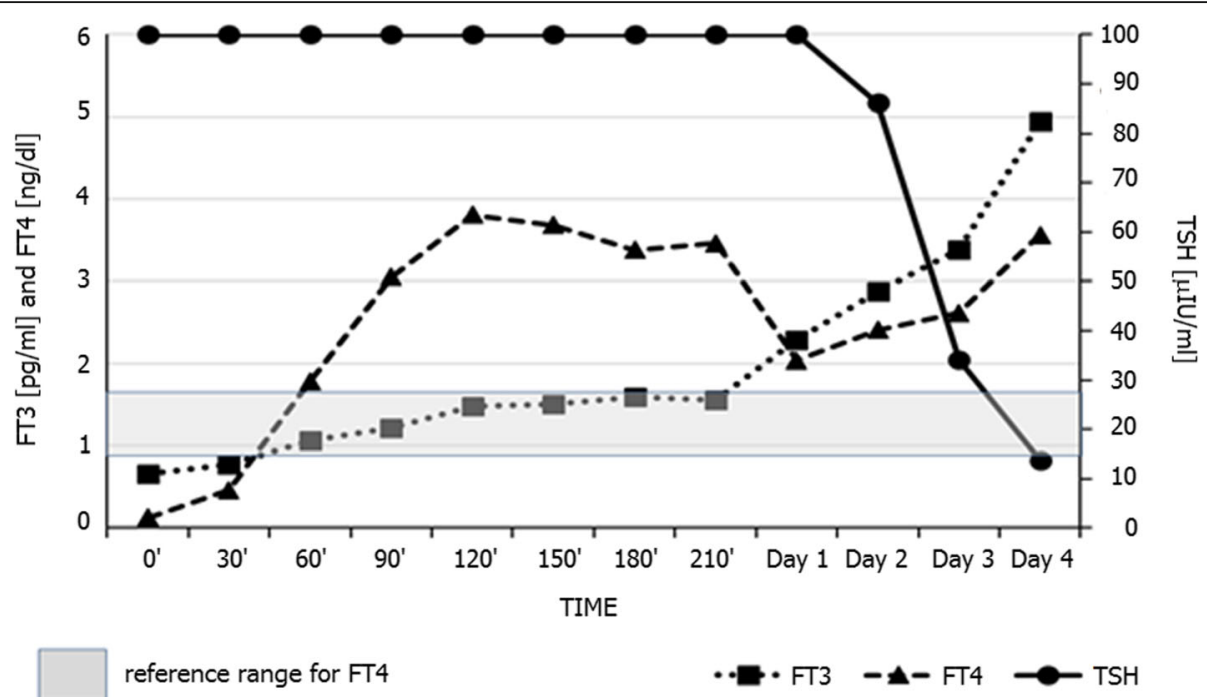

Fig. 2 Results of oral $2500 \mu \mathrm{g}$ levothyroxine absorption test in a female patient with suspected levothyroxine malabsorption performed in our Department under strict supervision. Darker area represents reference range for free $\mathrm{T}_{4}$ for our assay $(0.93-1.70 \mathrm{ng} / \mathrm{dl})$. Avid absorption of levothyroxine is clearly demonstrated followed by near normalization of TSH concentrations after 4 days

rather inadequate absorption of $\mathrm{LT}_{4}$ (Fig. 1). This had lead supervising physicians to reach an erroneous conclusion that the patient was suffering from a genuine malabsorption despite the lack of evidence of coeliac or other gastrointestinal diseases. In consequence, she had been put on both gluten and lactose-free diet that was followed by rather unsuccessful attempts to overcame presumed $\mathrm{LT}_{4}$ malabsorption with massive $\mathrm{LT}_{4}$ (and $\mathrm{T}_{3}$ doses) (Table 1). Prolonged ingestion of such high doses of $\mathrm{LT}_{4}$ might have been potentially very dangerous, if the patient had suddenly decided to follow the prescribed regimen.

It should be noted that paracetamol absorption test has widely been validated as a marker of gastric emptying [17], while coadministration of $\mathrm{LT}_{4}$ and paracetamol (i.e. a combined $\mathrm{LT}_{4} /$ paracetamol absorption test) was suggested as a good method to check for $\mathrm{LT}_{4}$ malabsorption [6]. It is not clear what kind of paracetamol formulation was administered during the test performed in our patient, but it is known that absorption of paracetamol is much faster if administered in a crushed form or together with bicarbonate. In case of paracetamol the time for maximal post-dose concentration $\left(t_{\max }\right)$ is about $1.58 \mathrm{~h}$ for standard tablets, but it decreases to as much as $0.42 \mathrm{~h}$ (about $25 \mathrm{~min}$ ), if co-administered with bicarbonate [18]. Indeed the study of Sanaka et al. [19] suggests that assessment of paracetamol concentrations (if given in a liquid form) can be performed as soon as after 15 and $30 \mathrm{~min}$ in order to reliably estimate gastric emptying.

In our case, the first assessment of $\mathrm{FT}_{4}$ and paracetamol concentrations were performed rather late, i.e. $2 \mathrm{~h}$ after ingestion of test doses. In our opinion, such timing impeded adequate supervision of the patient during the crucial absorption period (i.e. the first hour after tablet ingestion). In such cases a possibility of a manipulative behaviour must be always suspected. Notably, in a study by Thynne and Doogue [6] sampling was performed at hourly intervals during a four-hour period.

In our case there is a strong suspicion that the patient had not been supervised correctly, i.e. she was likely to swallow the tablets in a supervised manner, but must have been subsequently left unsupervised till the first blood sampling (i.e. after $120 \mathrm{~min}$ ). There is a possibility that if subsequently she had managed to provoke vomiting, e.g. 20-25 min after the test dose, then most of the paracetamol dose might have been already absorbed, in contrast to $\mathrm{LT}_{4}$ that is absorbed more slowly. This, in turn could result in misleading test result.

In contrast, in our Institution we have observed a very rapid absorption of $\mathrm{LT}_{4}$, when the patient was prevented from leaving the area, where blood samples were being collected at $30 \mathrm{~min}$ intervals. She was instructed that all patients who require frequent blood testing, e.g. during dynamic tests for pituitary function, had to remain in the nurse-supervised Endocrine Dynamic Test Room for the entire duration of the test. Importantly, she was aware that such procedure was not "designed" particularly for her, as other patients were also present. As a result of such approach, we have managed to ensure an adequate patient supervision and clearly demonstrated normal absorption of $\mathrm{LT}_{4}$. In such circumstances we have also demonstrated that there is no need to coadminister paracetamol. Furthermore, paracetamol absorption test without adequate supervision may be indeed misleading. In our case, though the patient 
discharged herself against medical advice, the diagnosis of deliberate non-compliance with medication regimen was established and her General Practitioner was informed about the outcome of our investigations. Furthermore, we offered a possibility of a supervised ingestion of her $\mathrm{LT}_{4}$ dose once a week. Such an approach was found to be safe and validated by several authors [20-22].

\section{Conclusion}

In summary, we have demonstrated that adequate supervision and frequent sampling is the key for successful implementation of $\mathrm{LT}_{4}$ absorption test in manipulative patients with deliberate medication non-adherence. Such an approach should obviate the need for several readmissions associated with enourmous costs for health service and multitude of unnecessary investigations. Furthermore, adequate supervision and frequent sampling during initial part of the test renders paracetamol coadministration superfluous.

\section{Abbreviations}

$\mathrm{FT}_{3}$ : Free triiodothyronine; $\mathrm{FT}_{4}$ : Free thyroxine; $\mathrm{LT}_{4}$ : Levothyroxine;

$\mathrm{T}_{3}$ : Triiodothyronine; TSH: Thyroid stimulating hormone

\section{Acknowledgements}

Study was supported by statutory funds from the Medical University of Lodz, Poland (no. 503/1-107-03/503-11-001-19-00).

\section{Authors' contributions}

$\mathrm{KCL}$ - principal physician responsible for clinical management, writing of the paper. KD, MB-L - clinical management, preparation of tables and Figures. AL - Head of the Department of Endocrinology and Metabolic Diseases, Medical University of Lodz, Poland, preparation and final revision of the manuscript. $M B$ - supervision and clinical management in the Department of Endocrinology, Diabetes and Isotope Therapy, Medical University of Wroclaw, Poland. MR - supervision and clinical management in the Department of Endocrinology and Metabolic Diseases, Medical University of Poznan, Poland. All authors have read and approved the final version of the manuscript.

\section{Funding}

Not applicable.

\section{Availability of data and materials}

Data availability from the authors on request.

\section{Ethics approval and consent to participate}

Ethical approval was obtained from the Ethics Committee of the "Polish Mothers'" Memorial Hospital Research Institute, Lodz, Poland.

\section{Consent for publication}

Due to public importance of the management of similar cases with a psychiatric component the Ethical Committee declared that the data can be published in an anonymous form for research and training purposes. No formal consent was obtained in such circumstances, given that the patient discharged herself against medical advice with full explanation of the risks associated with of severe hypothyroidism.

\section{Competing interests}

The authors declare that there are no competing interests.

\section{Author details}

'Department of Endocrinology and Metabolic Diseases, Medical University of Lodz, Rzgowska 281/289, 93-338 Lodz, Poland. ²Department of Endocrinology and Metabolic Diseases, Polish Mother's Memorial Hospital -
Research Institute, Lodz, Poland. ${ }^{3}$ Department of Endocrinology, Diabetes and Isotope Therapy, Medical University of Wroclaw, Wrocław, Poland.

${ }^{4}$ Department of Endocrinology and Metabolic Diseases, Medical University of Poznan, Poznan, Poland.

Received: 29 January 2020 Accepted: 6 May 2020

Published online: 18 May 2020

\section{References}

1. Lewandowski KC, Dąbrowska K, Komorowska-Dudek I, Lewiński A. A single bolus of high dose levothyroxine (L-T4) as a test in cases of suspected poor compliance to L-T4 therapy. Thyroid Res. 2015;8:16. https://doi.org/10.1186/ s13044-015-0028-0.

2. Walker JN, Shillo P, Ibbotson V, Vincent A, Karavitaki N, Weetman AP, et al. A thyroxine absorption test followed by weekly thyroxine administration: a method to assess non-adherence to treatment. Eur J Endocrinol. 2013;168: 913-7. https://doi.org/10.1530/EJE-12-1035.

3. Ching Sun GE, Pantalone KM, Faiman C, Gupta M, Olansky L, Hatipoglu B. The clinical utility of free thyroxine in oral levothyroxine absorption testing. Endocrine Pract. 2014;20(9):925-9. https://doi.org/10.4158/EP13487.OR.

4. Ismail AA, Walker PL, Barth JH, Lewandowski KC, Jones R, Burr WA. Wrong biochemistry results: two case reports and observational study in 5310 patients on potentially misleading thyroid-stimulating hormone and gonadotropin immunoassay results. Clin Chem. 2002;48:2023-9.

5. Lewandowski KC, Dąbrowska K, Lewiński A. Case report: When measured free $T_{4}$ and free T3 may be misleading. Interference with free thyroid hormones measurements on Roche $e^{\oplus}$ and Siemens ${ }^{\oplus}$ platforms. Thyroid Res. 2012;5:11. https://doi.org/10.1186/1756-6614-5-11.

6. Thynne TR, Doogue MP. A dose of paracetamol for the levothroxine absorption test. Clin Endocrinol. 2013;78:968-9. https://doi.org/10.1111/cen.12211.

7. Gibb IA, Anderson BJ. Paracetamol (acetaminophen) pharmacodynamics: interpreting the plasma concentration. Arch Dis Child. 2008;93:241-7. https://doi.org/10.1136/adc.2007.126896.

8. Favresse J, Burlacu MC, Maiter D, Gruson D. Interferences with thyroid function immunoassays: clinical implications and detection algorithm. Endocr Rev. 2018;39:830-50. https://doi.org/10.1210/er.2018-00119.

9. Marsh MN. Grains of truth: evolutionary changes in small intestinal mucosa in response to environmental antigen challenge. Gut. 1990;31:111-4. https:// doi.org/10.1136/gut.31.1.111.

10. Gattaz WF, Dressin H, Hewler W. Münchhausen syndrome: psychopathology and management. Psychopathology. 1990;23:33-9.

11. Van Wilder N, Bravenboer B, Herremans S, Vanderbruggen N, Velkeniers B. Pseudomalabsorption of levothyroxine: a challenge for the endocrinologist in the treatment of hypothyroidism. Eur Thyroid J. 2017;6(1):52-6. https:// doi.org/10.1159/000452489.

12. O'Shea B. Factitious disorders: the Baron's legacy. Intern J Psychiatry Clin Pract. 2003;7:33-9. https://doi.org/10.1080/13651500310001040.

13. Balla M, Jhingan RM, Rubin DJ. Rapid levothyroxine absorption testing: a case series of nonadherent patients. Int J Endocrinol Metab. 2015;13:e31051. https://doi.org/10.5812/ijem.31051.

14. Lips DJ, Van Reisen MT, Voigt V, Venekamp W. Diagnosis and treatment of levothyroxine pseudomalabsorption. Neth J Med. 2004;62:114-8.

15. Soares RMV, de Figueiredo RM, Melo Dantas MN, Solano Brito MV, Marinho MV, Pires Sousa AG, Lira da Camara V, LHC N, Lima JG. Rapid levothyroxine (Lt4) absorption test for diagnosis of IT4 pseudomalabsorption: Case report and proposal of a cutoff point. J Endocrinol Diabetes Obes. 2016:4(1):1083.

16. Yoshida T, Nakayama A, Tamura A, Higuchi S, Sakuma I, Nagano H, Felizola SJ, Hashimoto N, Takemoto M, Tatsuno I, Koide H, Yokote K, Tanaka T. A case of Hashimoto's thyroiditis with multiple drug resistance and high expression of efflux transporters. J Clin Endocrinol Metab. 2020;105:1-8. https://doi.org/10.1210/clinem/dgz073.

17. Willems $M$, Quartero AO, Numans ME. How useful is paracetamol absorption as a marker of gastric emptying? Dig Dis Sci. 2001;46:2256-62. https://doi.org/10.1023/a:1011935603893.

18. Moore RA, Derry S, Wiffen PJ, Straube S. Effects of food on pharmacokinetics of immediate release oral formulations of aspirin, dipyrone, paracetamol and NSAIDs - a systematic review. Br J Clin Pharmacol. 2015;80:381-8. https://doi.org/10.1111/bcp.12628.

19. Sanaka M, Koike Y, Yamamoto T, Mineshita S, Yamaoka S, Hirama S, et al. A reliable and convenient parameter of the rate of paracetamol absorption to 
measure gastric emptying rate of liquids. Int J Clin Pharmacol Ther. 1997;35: 509-13.

20. Thein-Wai W, Larsen PR. Effects of weekly thyroxine administration on serum thyroxine, 3,5,3'-triiodothyronine, thyrotropin, and the thyrotropin response to thyrotropin-releasing hormone. J Clin Endocrinol Metab. 1980; 50:560-4. https://doi.org/10.1210/jcem-50-3-560.

21. Grebe SKG, Cooke RR, Ford HC, Fagerstrom JN, Cordwell DP, Lever NA, et al. Treatment of hypothyroidism with once weekly thyroxine. J Clin Endocrinol Metab. 1997;82:870-5.

22. Moisey R, Swinburne J, Orme S. Assessment and management of noncompliant hypothyroid patients: the role of weekly observed thyroxine therapy. Endocrine Abstr. 2007;13:P298.

\section{Publisher's Note}

Springer Nature remains neutral with regard to jurisdictional claims in published maps and institutional affiliations.

Ready to submit your research? Choose BMC and benefit from:

- fast, convenient online submission

- thorough peer review by experienced researchers in your field

- rapid publication on acceptance

- support for research data, including large and complex data types

- gold Open Access which fosters wider collaboration and increased citations

- maximum visibility for your research: over $100 \mathrm{M}$ website views per year

At BMC, research is always in progress.

Learn more biomedcentral.com/submissions 